\title{
Microbiological quality of pasteurized milk on expiration date in Tehran, Iran
}

\author{
Mohammadreza Koushki, ${ }^{*}$ Paliz Koohy-Kamaly,, ${ }^{* 1}$ Mohammad Azizkhani, $\dagger$ and Noushin Hadinia† \\ *Research Department of Food Technology, and \\ †Students Research Committee, National Nutrition and Food Technology Research Institute, Faculty of Nutrition Sciences and Food Technology, \\ Shahid Beheshti University of Medical Sciences, PO Box 19395-4741, Tehran, Iran
}

\begin{abstract}
The aim of this study was to determine the microbiological quality of pasteurized milk on expiration date in Tehran. Two hundred fifty-four samples collected using a simple randomized sampling method from March 2014 to January 2015 were tested for total microbial count, coliform count, and Escherichia coli contamination according to Iran's National Standards methods. Total microbial count, coliform count, and E. coli contamination exceeded the standard limits in $61.1 \%$ [ $>7.5$ $\left.\times 10^{4}(4.88 \log ) \mathrm{cfu} / \mathrm{mL}\right], 24.4 \%$ [>10 $\left.(1 \mathrm{log}) \mathrm{cfu} / \mathrm{mL}\right]$, and $8.7 \%$ of the samples, respectively. The mean total microbial count $\left[7.1 \times 10^{7}(7.85 \mathrm{log}) \mathrm{cfu} / \mathrm{mL}\right]$ was above the standard limit. Only $36.6 \%$ of the studied samples were in accordance with Iran's National Standard limits. Based on our results, it is necessary to improve the microbial quality of pasteurized milk in Iran.
\end{abstract}

Key words: pasteurized milk, microbiological quality, shelf life

\section{INTRODUCTION}

Milk is a nutritious and valuable food product at any age (Koushki, 2009; Schaafsma, 2009) and, in many countries, dairy products form a large portion of the daily diet of people, especially infants and children. As milk is a rich source of nutrients, it is a suitable growth medium for pathogenic and spoilage microorganisms (Robinson, 2002; Oliver et al., 2005). Moreover, microbial characteristics of milk may directly affect the flavor and physicochemical properties of dairy products (Allen and Joseph, 1985; Simon and Hansen, 2001; Robinson, 2002). Various outbreaks of foodborne illnesses associated with the consumption of pasteurized milk or pasteurized dairy products have been reported previously (CDC, 2008; Schmid et al., 2009; Koch et al., 2010; Jackson et al., 2011).

Received September 15, 2015.

Accepted November 20, 2015.

${ }^{1}$ Corresponding author: pkoohy@sbmu.ac.ir or pkoohy@gmail.com
Although many studies have been conducted on the microbiological quality of pasteurized milk in different parts of the world (Ranieri and Boor, 2009; Breurec et al., 2010; Silva et al., 2010; Anderson et al., 2011; Martin et al., 2012; Belli et al., 2013; Quigley et al., 2013; Kamana et al., 2014), only a few studies, with limited numbers of samples and regions, have been reported about microbial contamination of pasteurized milk in Iran (Fadaei et al., 2008; Vahedi et al., 2013; Teymori et al., 2014; Koushki and Koohy Kamaly, 2016). The aim of this study was to evaluate the microbiological quality of pasteurized milk sold in Tehran on its expiration date.

\section{MATERIALS AND METHODS}

\section{Sample Collection and Microbial Evaluation}

Two hundred fifty-four samples of pasteurized milk were collected from local markets affiliated with the Fruit and Vegetable Organization in different parts of Tehran, Iran, using a simple randomized sampling method from March 2014 to January 2015. The collected samples were transported to the laboratory in a cool box and kept in the refrigerator until the expiration date. Microbial tests including total microbial count (TMC; ISIRI, 2000a, 2007a), coliform count (ISIRI, 2000b, 2007b), and Escherichia coli contamination (ISIRI, 2000c, 2005) were conducted by the methods determined in Iran's National Standards (INS). Duplicate plates were used for microbial enumerations. The results were analyzed according to the INS limits for pasteurized milk (ISIRI, 2008).

\section{Statistical Analysis}

Statistical analysis was performed using SPSS software, version 17 (SPSS Inc./IBM Corp., Chicago, IL). Although descriptive statistics were used in this study, the Chi-squared test was performed to assess the relationship between the variables of interest; $P$-values $<$ 0.05 were considered significant. 


\section{RESULTS AND DISCUSSION}

According to the microbiological criteria for pasteurized milk recommended by INS, counts of total aerobic mesophilic microorganisms and coliforms should not exceed $7.5 \times 10^{4}(4.88 \mathrm{log}) \mathrm{cfu} / \mathrm{mL}$ and $10(1 \mathrm{log}) \mathrm{cfu} /$ $\mathrm{mL}$, respectively, and E. coli should be absent (ISIRI, 2008). In the present study, the microbial quality of only $36.6 \%$ of the studied samples was in accordance with the INS limits (ISIRI, 2008; Table 1).

Microbial and physicochemical quality of 38.5 and $45.7 \%$ of the 348 pasteurized milk samples was in accordance with the Agriculture Ministry Standards in Brazil (Da Silva et al., 2008). In Senegal, 93\% of pasteurized milk samples, $92 \%$ of raw milk samples, and $81 \%$ of sour milk samples failed to meet official standards (Breurec et al., 2010). In a 10-yr study on the microbial quality of liquid milk in New York State, percentages of the samples with bacterial counts less than that set by the Pasteurized Milk Ordinance $(2 \times$ $10^{4} \mathrm{cfu} / \mathrm{mL}$ ) increased from $21.1 \%$ in 2002 to $48.6 \%$ in 2010 (Martin et al., 2012). In West Azerbaijan Province (Iran), 85\% of studied pasteurized milk samples had acceptable microbial quality; however, only 10 samples were tested in that study (Teymori et al., 2014).

All microbial parameters determined by INS, including total aerobic mesophilic microorganism count (total microbial count), coliform count, and E. coli were above the standard limit in $7.1 \%$ of the studied samples (Table 1). Poor microbial quality of pasteurized milk may be caused by different factors such as microbial load of the raw milk, postprocessing contamination, and factors related to cold chain and hygienic parameters.

Total microbial count, coliform count, and E. coli contamination exceeded the standard limits in 61.1, 24.4 , and $8.7 \%$ of the samples, respectively, in the current study (Table 2 ).

Total microbial count is an indicator of the hygienic quality of food products. Coliform count and E. coli contamination are indicators of fecal contamination caused by pasteurization deficiency, secondary contamination, and type of packaging (Tortorella, 2003; Wong et al., 2010).

In the research of Silva et al. (2010), coliform counts at $35^{\circ} \mathrm{C}$ and $45^{\circ} \mathrm{C}$ and aerobic mesophilic count were not in accordance with the current standards in $70.8,57.5$, and $40 \%$ of 120 tested samples. In a study conducted in Turkey, 20 and $5 \%$ of the pasteurized milk samples did not comply with the Turkish Food Codex limits for total aerobic mesophilic bacteria and E. coli count, respectively (Çardad and Yilmaz, 2011). In Brazil, more than $40 \%$ of the 260 milk samples were unacceptable by coliform count according to the official standards of the country (Zanella et al., 2010).

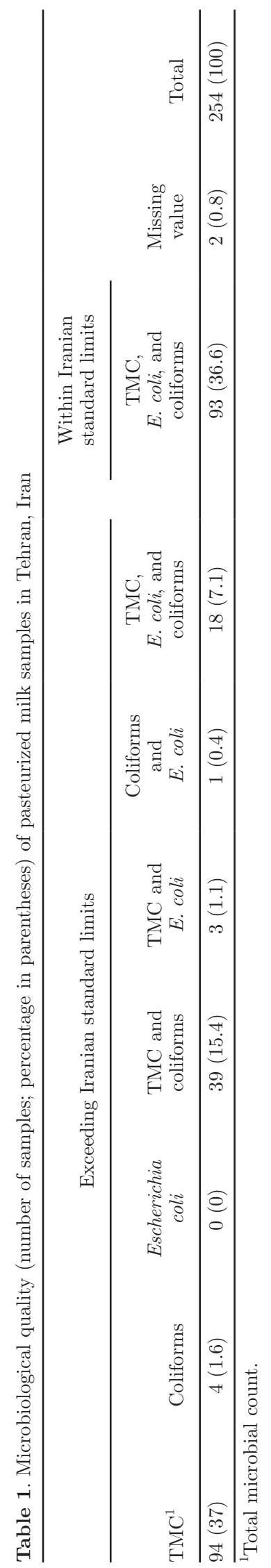

Journal of Dairy Science Vol. 99 No. 3, 2016 


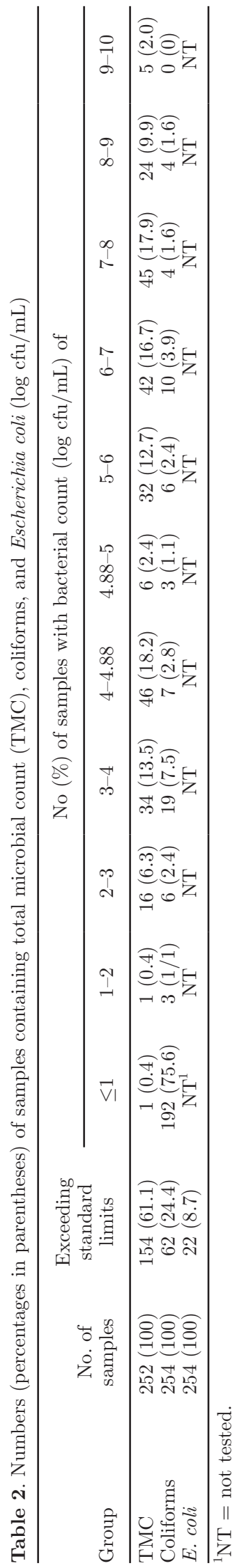

In the current study, $8.7 \%$ of the studied samples were contaminated by E. coli (Table 2). Contamination by $E$. coli was detected in 9\% (Vahedi et al., 2013), 18.05\% (Azad and Asghari-Rad, 2014), and 39.5\% (Shojaei and Yadollahi, 2008) of pasteurized milk samples in Sari (Iran), Urmia (Iran), and Shahrekord (Iran), respectively. Escherichia coli was isolated from $3.9 \%$ of samples analyzed in South Africa (El-Zubeir et al., 2008). In another study, 33.3\% of grade A pasteurized milks had fecal coliform counts above the Brazilian standard limits (da Silva et al., 2010). In contrast, E. coli was detected in only 1 of 20 samples in Jamaica (Anderson et al., 2011). In a similar study in Goa State, India, none of the packaged samples had coliform or $E$. coli contamination (Surve et al., 2011).

In the current research, the means of TMC $\left[7.1 \times 10^{7}\right.$ $(7.85 \mathrm{log}) \mathrm{cfu} / \mathrm{mL}]$ and coliform count $\left[6 \times 10^{6}(6.78\right.$ $\log ) \mathrm{cfu} / \mathrm{mL}$ ] exceeded INS limits (Table 3). Although the coliform count mean was above the limit, $75.6 \%$ of the studied samples had coliform counts within the standard limit, and only $24.4 \%$ of the samples had coliform counts higher than the standard limit (Table 2). The means of total bacterial count and total coliform count of the pasteurized milk samples in Shahrekord were reported to be $7.1 \times 10^{5} \mathrm{cfu} / \mathrm{mL}$ and $8 \times 10^{2} \mathrm{cfu} /$ $\mathrm{mL}$, respectively (Shojaei and Yadollahi, 2008). Various results were obtained from several countries for mean total microbial count and coliform count, respectively: $9.9 \times 10^{5}$ and $2.8 \times 10^{4} \mathrm{cfu} / \mathrm{mL}$ (South Africa; ElZubeir et al., 2008), $3.4 \times 10^{4}$ and $2.8 \times 10^{2} \mathrm{cfu} / \mathrm{mL}$ (Venezuela; Valbuena et al., 2004), $3.72 \pm 0.62$ and $1.92 \pm 1.86 \mathrm{log} \mathrm{cfu} / \mathrm{mL}$ (Cameroon; Belli et al., 2013), 4.6 and $1.4 \log \mathrm{cfu} / \mathrm{mL}$ (Rwanda; Kamana et al., 2014), and $16.586 \pm 12.868$ and $66 \pm 72 \mathrm{log} \mathrm{cfu} / \mathrm{mL}$ (Zambia; Kunda et al., 2015). In Poland, total bacterial count in high-temperature pasteurized milk at the end of shelf life was very low ( $<1 \mathrm{cfu} / \mathrm{mL}$; Piotrowska et al., 2015). The results from the above-mentioned studies were lower than the means of TMC and coliform count in the present study. All of these studies except the last were conducted within the shelf-life period, whereas we evaluated the quality of milk samples on the day of expiration (i.e., the last day of shelf life). Moreover, factors such as raw milk microbial load and cold chain may lead to the high microbial count.

In the present study, the TMC in $46.5 \%$ of the pasteurized milk samples exceeded $10^{6}(6 \log ) \mathrm{cfu} / \mathrm{mL}$, the limit set by INS (ISIRI, 2008) for the total microbial count of raw milk (Table 2). As pasteurized milk undergoes a heat treatment, such a high total microbial count may be the result of low hygienic level, deficient cold chain, or deficient pasteurization process. The microbial load of raw milk might explain the high TMC of pasteurized milk (Gruetzmacher and Bradley, 1999). 
Table 3. Descriptive statistics of microbiological results of pasteurized milk samples in Tehran, Iran

\begin{tabular}{lcccccc}
\hline Count & Mean $\pm \mathrm{SD}$ & $\begin{array}{c}25 \text { th } \\
\text { Percentile }\end{array}$ & Median & 75th Percentile & Minimum & Maximum \\
\hline TMC, ${ }^{1}$ Log cfu/mL & $7.85 \pm 8.45$ & 4.20 & 5.54 & 7.15 & $<1$ & 9.39 \\
Coliforms, Log cfu/mL & $6.78 \pm 7.72$ & $<1$ & $<1$ & 1 & $<1$ & 8.87 \\
\hline
\end{tabular}

${ }^{1}$ Total microbial count.

Previous studies confirmed an unacceptable TMC of raw milk in different parts of Iran (Movassagh Ghazani et al., 2008; Fadaei, 2014). Cold chain is also a crucial factor affecting the microbial quality of raw and pasteurized milk. Breaking the cold chain in some stages may lead to an increase of TMC (Koushki, 2009). In Iran, pasteurized milk packages are kept under continuous refrigeration in the factory and all deliveries are conducted using refrigerated vehicles but there is no control of the cold chain during transportation. Due to the high consumption of pasteurized milk in Tehran, pasteurized milk is transported from other parts of Iran to Tehran, and the cold chain may be compromised during transportation of pasteurized milk from distant cities. In the market place, milk bottles are always refrigerated; however, milk pouches may be kept out of the refrigerator until they are sold. Breaking the cold chain at this stage may lead to an increase in TMC. In Rwanda, the increase of bacterial counts in supermarkets was related to compromising the cold chain and switching off refrigerators at night to save energy (Kamana et al., 2014). In Iran, farmers deliver their milk in milk cans directly, or indirectly by an intermediary, to milk collection centers. At this stage, temperature and other conditions may be uncontrolled. Then, the collected milk is transported in tankers from the milk collection centers to the milk plants. As a result, cold chain breakage might occur before delivery of milk to the factory, which results in the high TMC of the raw milk.

Our findings showed a significant statistical correlation between TMC and coliform count $(\mathrm{r}=0.426, P<$ 0.001). This result is in agreement with another study, which showed a positive significant statistical correla- tion between total microbial count and presence of total and fecal coliforms (Srikandakumar et al., 2004).

In our investigation, the percentage of samples with total microbial counts above the standard limit was significantly lower in winter than in other seasons $(P=$ 0.034; Table 4). Obviously, when the ambient temperature is higher, breaking the cold chain during long-distance transportation is more likely to increase the TMC of the milk. However, we detected no significant difference between the percentage of samples with coliform counts above the standard limit and season (Table 4). In research conducted in Oman, season had no effect on TMC, total coliform count, or fecal coliforms (Srikandakumar et al., 2004). In a similar study in Shahrekord (Iran), coliform counts of all pasteurized milk samples were within the standard limits $[<10(1 \log ) \mathrm{cfu} / \mathrm{mL}]$; however, the number of coliform-contaminated samples collected was greater in summer than in winter $(P<$ 0.05; Fadaei et al., 2008).

Although none of the collected samples in winter were contaminated with $E$. coli, we found no significant statistical correlation between $E$. coli contamination and season (Table 4). In a study conducted in Urmia (Iran), the highest percentage of $E$. coli-contaminated samples (46.38\%) was found in summer (Azad and Asghari-Rad, 2014).

In the present research, we detected no significant difference between shelf life and coliform count and total microbial count status (Table 5). However, the shelf life of $E$. coli-contaminated samples was significantly different $(P=0.015)$. In South Africa, no significant difference was observed between the expiration date and TMC, coliform count, and E. coli; however, expira-

Table 4. Microbiological status (number; percentage in parentheses) of pasteurized milk samples according to season

\begin{tabular}{|c|c|c|c|c|c|c|c|}
\hline \multirow[b]{2}{*}{ Season } & \multicolumn{2}{|c|}{$\begin{array}{l}\text { Total microbial count } \\
\quad(\mathrm{Log} \mathrm{cfu} / \mathrm{mL})\end{array}$} & \multicolumn{2}{|c|}{$\begin{array}{l}\text { Coliform count } \\
(\mathrm{Log} \mathrm{cfu} / \mathrm{mL})\end{array}$} & \multicolumn{2}{|c|}{ E. coli contamination } & \multirow[b]{2}{*}{ Total } \\
\hline & $\leq 4.88$ & $>4.88$ & $\leq 1$ & $>1$ & Positive & Negative & \\
\hline Summer & $30(36.6)$ & $52(63.4)$ & $55(67.1)$ & $27(32.9)$ & $71(86.6)$ & $11(13.4)$ & $82(100)$ \\
\hline Autumn & $37(38.5)$ & $59(61.5)$ & $76(79.2)$ & $20(20.8)$ & $89(92.7)$ & $7(7.3)$ & $96(100)$ \\
\hline Winter & $11(73.3)$ & $4(26.7)$ & $12(80)$ & $0.188^{J}$ & $15(100)$ & $0(0)$ & $15(100)$ \\
\hline
\end{tabular}


Table 5. Microbiological status (number; percentage in parentheses) of pasteurized milk samples according to shelf life

\begin{tabular}{|c|c|c|c|c|c|c|c|}
\hline \multirow[b]{2}{*}{ Shelf life ${ }^{1}$} & \multicolumn{2}{|c|}{$\begin{array}{l}\text { Total microbial count } \\
\quad(\log \mathrm{cfu} / \mathrm{mL})\end{array}$} & \multicolumn{2}{|c|}{$\begin{array}{l}\text { Coliform count } \\
(\mathrm{Log} \mathrm{cfu} / \mathrm{mL})\end{array}$} & \multicolumn{2}{|c|}{$\begin{array}{l}\text { Escherichia coli } \\
\text { contamination }\end{array}$} & \multirow[b]{2}{*}{ Total } \\
\hline & $\leq 4.88$ & $>4.88$ & $\leq 1$ & $>1$ & Positive & Negative & \\
\hline$\overline{5} \mathrm{~d}$ & $42(32.8)$ & $86(67.2)$ & $94(72.9)$ & $35(27.1)$ & $10(7.8)$ & $119(92.2)$ & $129(100)$ \\
\hline $6 \mathrm{~d}$ & $31(41.3)$ & $44(58.7)$ & \multirow{2}{*}{\multicolumn{2}{|c|}{$63(82.9){ }_{0.288}^{13(17.1)}$}} & \multirow{2}{*}{\multicolumn{2}{|c|}{0.015}} & $76(100)$ \\
\hline$P$-value & \multicolumn{2}{|c|}{0.083} & & & & & \\
\hline
\end{tabular}

${ }^{1}$ Shelf life is calculated from the difference between the production and expiration dates labeled by the manufacturer.

tion date and somatic cell count were correlated $(P<$ 0.0001; El-Zubeir et al., 2008).

\section{CONCLUSIONS}

In the present study, $36.6 \%$ of the samples were in accordance with the Iranian National Standard limits. The mean of total microbial count exceeded the limit, and $46.5 \%$ of the samples had high total microbial count $\left[>10^{6}(6 \mathrm{log}) \mathrm{cfu} / \mathrm{mL}\right]$. Although the mean of coliform count was above the INS limit, $76.6 \%$ of samples had coliform counts in compliance with the INS limit. Only $8.7 \%$ of our samples were contaminated with $E$. coli. It is necessary to improve pasteurized milk quality and address factors influencing the quality of milk, such as the cold chain, in Iran.

\section{ACKNOWLEDGMENTS}

The authors are grateful for the financial support of this project provided by the National Nutrition and Food Technology Research Institute, Shahid Beheshti University of Medical Sciences (Tehran, Iran).

\section{REFERENCES}

Allen, J. C., and G. Joseph. 1985. Deterioration of pasteurized milk on storage. J. Dairy Res. 52:469-487.

Anderson, M., P. Hinds, S. Hurditt, P. Miller, D. McGrowder, and R. Alexander-Lindo. 2011. The microbial content of unexpired pasteurized milk from selected supermarkets in a developing country. Asian Pac. J. Trop. Biomed. 1:205-211.

Azad, H., and S. Asghari-Rad. 2014. Evaluation of pasteurized milk, E. coli contamination in Urmia in 6 months of 2013. In the 22nd National Congress on Food Science and Technology of Iran. Gorgan University of Agricultural Sciences and Natural Resources, Gorgan, Iran. [In Persian]

Belli, P., A. F. A. Cantafora, S. Stella, S. Barbieri, and C. Crimella. 2013. Microbiological survey of milk and dairy products from a small scale dairy processing unit in Maroua (Cameroon). Food Control 32:366-370.

Breurec, S., R. Poueme, C. Fall, A. Tall, A. Diawara, R. BadaAlambedji, C. Broutin, A. Leclercq, and B. Garin. 2010. Microbiological quality of milk from small processing units in Senegal. Foodborne Pathog. Dis. 7:601-604.

Cardad, A. D., and M. Yilmaz. 2011. Survey of the bacteriological quality of dairy products in the province of Aydin, Turkey. Milchwissenschaft 66:304-306.
CDC (Centers for Disease Control and Prevention). 2008. Outbreak of Listeria monocytogenes infections associated with pasteurized milk from a local dairy-Massachusetts, 2007. MMWR Morb. Mortal. Wkly. Rep. 57:1097-1100.

Da Silva, M. C. D., J. V. L. Da Silva, A. C. S. Ramos, R. D. O. Melo, and J. O. Oliveira. 2008. Microbiological and physico-chemical characterization of pasteurized milk for the milk program in the State of Alagoas. Cienc. Tecnol. Aliment. 28:226-230.

da Silva, V. A. M., P. M. Rivas, M. B. Zanela, A. T. Pinto, M. E. R. Ribeiro, F. F. P. da Silva, and M. Machado. 2010. Evaluation of physical, chemical and microbiological quality of raw and pasteurized grade A milk and points of contamination at a dairy farm in RS. Acta Sci. Vet. 38:51-57.

El-Zubeir, I. E. M., V. Gabriechise, and Q. Johnson. 2008. Comparison of chemical composition and microbial profile of raw and pasteurized milk of the Western Cape, South Africa. Int. J. Dairy Sci. $3: 137-143$.

Fadaei, A. 2014. Bacteriological quality of raw cow milk in Shahrekord, Iran. Vet. World 7:240-243.

Fadaei, A., E. Jamshidi, and S. Kheiri. 2008. Comparison of bacterial contamination of raw and pasteurized milk used in Shahrekord in 2006. J. Shahrekord Univ. Med. Sci. 10:37-44. (In Persian)

Gruetzmacher, T. J., and R. L. Bradley Jr.. 1999. Identification and control of processing variables that affect the quality and safety of fluid milk. J. Food Prot. 62:625-631.

ISIRI. 2000a. Milk and milk products-Enumeration of colony-forming units of : colony count technique at $30^{\circ} \mathrm{C}$. National Standard No. 5484. Institute of Standards and Industrial Research of Iran, Tehran, Iran.

ISIRI. 2000b. Milk and milk products_-Enumeration of coliforms, part 1: Colony count technique at $30^{\circ} \mathrm{C}$ without resuscitation. National Standard No. 5486-1. Institute of Standards and Industrial Research of Iran, Tehran, Iran.

ISIRI. 2000c. Milk and milk products - Enumeration of presumptive Escherichia coli: Most probable number technique. National Standard No. 5234. Institute of Standards and Industrial research of Iran, Tehran, Iran.

ISIRI. 2005. Microbiology of food and animal feeding stuffs-Detection and enumeration of presumptive Escherichia coli: Most probable number technique. National Standard No. 2946. Institute of Standards and Industrial research of Iran, Tehran, Iran.

ISIRI. 2007a. Microbiology of food and animal feeding stuffs-Horizontal method for the enumeration of microorganisms: Colony count technique at $30^{\circ} \mathrm{c}$. National Standard No. 5272. Institute of Standards and Industrial research of Iran, Tehran, Iran.

ISIRI. 2007b. Microbiology of food and animal feeding stuffs-Horizontal method for the enumeration of coliforms: Colony-count technique. National Standard No. 9263. Institute of Standards and Industrial research of Iran, Tehran, Iran.

ISIRI. 2008. Microbiology of milk and milk products - Specifications. National Standard No. 2406. Institute of Standards and Industrial Research of Iran, Tehran, Iran.

Jackson, K. A., M. Biggerstaff, M. Tobin-D'Angelo, D. Sweat, R. Klos, J. Nosari, O. Garrison, E. Boothe, L. Saathoff-Huber, L. Hainstock, and R. P. Fagan. 2011. Multistate outbreak of Listeria monocytogenes associated with Mexican-style cheese made from 
pasteurized milk among pregnant, Hispanic women. J. Food Prot. 74:949-953.

Kamana, O., S. Ceuppens, L. Jacxsens, A. Kimonyo, and M. Uyttendaele. 2014. Microbiological quality and safety assessment of the Rwandan milk and dairy chain. J. Food Prot. 77:299-307.

Koch, J., R. Dworak, R. Prager, B. Becker, S. Brockmann, A. Wicke, H. Wichmann-Schauer, H. Hof, D. Werber, and K. Stark. 2010. Large listeriosis outbreak linked to cheese made from pasteurized milk, Germany, 2006-2007. Foodborne Pathog. Dis. 7:1581-1584.

Koushki, M. 2009. Milk, Meat and Egg Technology. 1st ed. Sarva Publication, Tehran, Iran [in Persian].

Koushki, M., and P. Koohy Kamaly. 2016. Microbiological quality of pasteurized milk in west of Tehran (Winter 2012). Iran. J. Food Sci. Technol. 13:115-120. (in Persian).

Kunda, B., G. S. Pandey, C. Mubita, J. B. Muma, and C. Mumba. 2015. Compositional and microbial quality of heat-treated milk brands marketed in Lusaka, Zambia. Livest. Res. Rural Dev. 27. Article \#143. Accessed Dec. 23, 2015. http://www.lrrd.org/ $\operatorname{lrrd} 27 / 7 /$ kund27143.htm.

Martin, N. H., N. R. Carey, S. C. Murphy, M. Wiedmann, and K. J. Boor. 2012. A decade of improvement: New York State fluid milk quality. J. Dairy Sci. 95:7384-7390.

Movassagh Ghazani, M. H., A. R. Karami, J. Dolgharisharf, M. Khajeh, and K. Najafian. 2008. Microbiological safety of raw milk in Tabriz, Iran. J. Anim. Vet. Adv. 7:863-865.

Oliver, S. P., B. M. Jayarao, and R. A. Almeida. 2005. Foodborne pathogens in milk and the dairy farm environment: Food safety and public health implications. Foodborne Pathog. Dis. 2:115-129.

Piotrowska, A., F. Świderski, E. Kostyra, M. Żebrowska-Krasuska, and A. Sadowska. 2015. Microbiological and sensory quality of milk on the domestic market. Pol. J. Food Nutr. Sci. 65:261-268. http://dx.doi.org/10.1515/pjfns-2015-0008.

Quigley, L., R. McCarthy, O. O'Sullivan, T. P. Beresford, G. F. Fitzgerald, R. P. Ross, C. Stanton, and P. D. Cotter. 2013. The microbial content of raw and pasteurized cow milk as determined by molecular approaches. J. Dairy Sci. 96:4928-4937.

Ranieri, M. L., and K. J. Boor. 2009. Short communication: Bacterial ecology of high-temperature, short-time pasteurized milk processed in the United States. J. Dairy Sci. 92:4833-4840.

Robinson, R. K. 2002. Dairy Microbiology Handbook: The Microbiology of Milk and Milk Products. 3rd ed. John Wiley and Sons Limited, Chichester, UK

Schaafsma, G. 2009. Health benefits of milk beyond traditional nutrition. Aust. J. Dairy Technol. 64:113-116.
Schmid, D., R. Fretz, P. Winter, M. Mann, G. Höger, A. Stöger, W. Ruppitsch, J. Ladstätter, N. Mayer, A. De Martin, and F. Allerberger. 2009. Outbreak of staphylococcal food intoxication after consumption of pasteurized milk products, June 2007, Austria. Wien. Klin. Wochenschr. 121:125-131.

Shojaei, Z., and A. Yadollahi. 2008. Physicochemical and microbiological quality of raw, pasteurized and UHT milks in shops. Asian J. Sci. Res. 1:532-538.

Silva, R., A. G. Cruz, J. A. F. Faria, M. M. L. Moura, L. M. J. Carvalho, E. H. M. Water, and A. S. Sant'Ana. 2010. Pasteurized milk: Efficiency of pasteurization and its microbiological conditions in Brazil. Foodborne Pathog. Dis. 7:217-219.

Simon, M., and A. P. Hansen. 2001. Effect of various dairy packaging materials on the shelf life and flavor of pasteurized milk. J. Dairy Sci. 84:767-773.

Srikandakumar, A., E. H. Johnson, H. Nsanzi, and K. S. Al-Abri. 2004. Microbes and anti-microbial substances in pasteurized milk sold in Oman. Int. J. Food Prop. 7:615-627.

Surve, V., M. Patil, and S. Gaikwad. 2011. Microbiological quality of milk marketed in Goa state. J. Dairy Foods Home Sci. 30:75-76.

Teymori, R., N. Ghazanfarirad, K. Dehghan, A. Kheyri, G. Hajigholizadeh, B. Kazemi-Ghoshchi, and M. Bahmani. 2014. Monitoring microbial quality of commercial dairy products in West Azerbaijan province, northwest of Iran. Asian Pac. J. Trop. Dis. 4(S2):S824-S829.

Tortorello, M. L. 2003. Indicator organisms for safety and quality - Uses and methods for detection. Minireview. J. AOAC Int. $86: 1208-1217$

Vahedi, M., M. Nasrolahei, M. Sharif, and A. M. Mirabi. 2013. Bacteriological study of raw and unexpired pasteurized cow's milk collected at the dairy farms and super markets in Sari city in 2011. J. Prev. Med. Hyg. 54:120-123.

Valbuena, E., G. Castro, K. Lima, W. Acosta, W. Bríñez, and A. Tovar. 2004. Bacteriological quality of main pasteurized milk brands distributed in Maracaibo city, Venezuela. Rev. Cient. Fac. Cienc. Vet. Univ. Zulia 14:59-67.

Wong, T., I. N. Haynes, and D. W. Eddy. 2010. Using indicator organisms for quality and safety in dairy manufacturing. Aust. J. Dairy Technol. 65:113-117.

Zanella, G. N., J. M. G. Mikcha, E. Bando, V. L. D. Siqueira, and M. J. Machinski. 2010. Occurrence and antibiotic resistance of coliform bacteria and antimicrobial residues in pasteurized cow's milk from Brazil. J. Food Prot. 73:1684-1687. 